\title{
Overexpression of $\beta$-Catenin Decreases the Radiosensitivity of Human Nasopharyngeal Carcinoma CNE-2 Cells
}

\author{
Huocong He ${ }^{a, b} \quad K e y u$ Lin ${ }^{a, b} \quad$ Ying Su ${ }^{a, b}$ Shaojun Lin ${ }^{b, c} \quad$ Changyan Zou ${ }^{a, b}$ \\ Jianru Pan ${ }^{d}$ Yan Zhou ${ }^{\text {Chao Chen }}{ }^{a, b}$ \\ aLaboratory of Radiation Oncology and Radiobiology, Fujian Cancer Hospital \& Fujian Medical \\ University Cancer Hospital, Fuzhou, bFujian Key Laboratory of Translational Cancer Medicine, \\ Fuzhou, 'Department of Radiation Oncology, Fujian Cancer Hospital \& Fujian Medical University, \\ Fuzhou, ${ }^{d}$ College of Biological Science and Engineering, Fuzhou University, Fuzhou, eDepartment of \\ Epidemiology, Fujian Cancer Hospital \& Fujian Medical University Cancer Hospital, Fuzhou, China
}

\author{
Key Words \\ $\beta$-catenin • Overexpression • Nasopharyngeal carcinoma $・$ Radiosensitivity
}

\begin{abstract}
Background/Aims: Nasopharyngeal carcinoma (NPC) is rare worldwide but remains highly prevalent in endemic regions, notably in southern China. Radiotherapy remains the treatment of choice for NPC, but radioresistance has been identified as a major cause of therapeutic failure. The $W n t / \beta$-catenin signaling has been found to be involved in NPC radioresistance; however, the effect of $\beta$-catenin overexpression on radioresistance remains unknown in NPC until now. This study aimed to examine the impact of $\beta$-catenin overexpression on the radiosensitivity of human NPC CNE-2 cells. Methods: Immunohistochemistry was performed to detect the $\beta$-catenin expression in normal nasopharyngeal specimens and NPC specimens. The human NPC CNE-2 cell line overexpressing $\beta$-catenin was modeled by transfection with the pcDNA3.1/Hygro $(+) / \beta$-catenin recombinant vector (transfection group), while cells transfected with the pcDNA3.1/Hygro(+) vector served as negative controls and nontransfected cells served as blank controls. The expression of key molecules of the $\mathrm{Wnt} / \beta$ catenin signaling pathway was determined using Western blotting and qPCR assays, and the changes of radiation sensitivity were measured with a colony-formation assay. Cell viability was measured by the MTT (3-(4,5-dimethylthiazol-2-yl)-2,5 -diphenyltetrazolium bromide) assay. In addition, the cell cycle and apoptosis was detected using flow cytometry and the TCF/LEF transcriptional activity was measured with a Dual Luciferase Reporter Assay System. Results: Immunohistochemical staining showed high $\beta$-catenin expression in radioresistant NPC specimens, and low expression in radiosensitive NPC specimens and normal nasopharyngeal specimens. Western blotting and qPCR assays detected higher $\beta$-catenin expression in the transfection group than in the negative and blank controls $(P<0.01)$. Down-regulation of GSK-

$\mathrm{H}$. He and K. Lin contributed equally to this work.
\end{abstract}

Ying Su

KARGER
Laboratory of Radiation Oncology and Radiobiology, Fujian Med. Univ.

Cancer Hospital, No. 420 Fuma Road, Fuzhou City (China)

E-Mail zjsuying@hotmail.com 


\section{Cellular Physiology Cell Physiol Biochem 2018;50:1929-1944

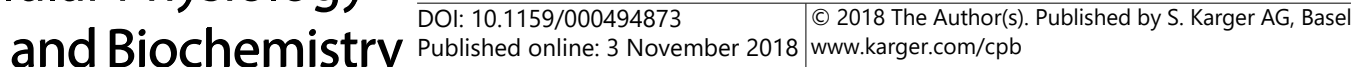 \\ He et al.: $\beta$-Catenin Overexpression Decreases CNE-2 Cell Radiosensitivity}

$3 \beta$ expression $(P<0.05)$ and up-regulation of Cyclin D1 expression $(P<0.01)$ was detected in $\beta$-catenin overexpressing NPC cells exposed to $X$-ray radiation relative to negative and blank controls. Colony-formation assay revealed higher $D_{0^{\prime}} D_{\mathrm{q}}$ and SF in the transfection group than in the negative and blank control groups post-radiation, and the SER in the transfection group was 0.75 -fold and 0.68 -fold greater than that in the blank and negative control groups, respectively. MTT assay revealed that the viability of CNE-2 cells was significantly higher in the transfection group $(96 \% \pm 8.72 \%)$ than in the negative control group $(74.67 \pm 7.05 \%)$ and the blank control group $(75.33 \% \pm 7.02 \%) 24$ h post-exposure to $6 \mathrm{~Gy}$ X-ray radiation $(P<$ $0.05)$. X-ray radiation led to a lower proportion of CNE-2 cells at the G2/M phase and a lower apoptotic rate in the transfection group than in the negative and blank control groups $(P<$ $0.05)$. In addition, the TCF/LEF transcriptional activity was higher in the transfection group than in the negative and blank control groups $(P<0.01)$, and 6 Gy $\mathrm{X}$-ray radiation elevated the TCF/LEF transcriptional activity relative to 0 Gy radiation in the transfection group $(P<0.01)$. Conclusion: $\beta$-catenin overexpression may decrease the radiation sensitivity in NPC CNE-2 cells through activating the downstream transcriptional factors of $\beta$-catenin, and reducing G2/M arrest and cell apoptosis.

\section{Introduction}

Nasopharyngeal carcinoma (NPC) is the most common primary malignancy in the nasopharynx [1, 2]. Although NPC is rare worldwide [3], this malignancy remains highly prevalent in endemic regions, notably in southern China [4]. Currently, radiotherapy remains the treatment of choice for NPC, and concomitant chemoradiotherapy has been proved to increase the survival [5,6]. Although $80 \%$ to $90 \%$ 5-year local control rates are achieved for NPC, there are still $20 \%$ to $30 \%$ of patients developing distal metastasis [7], and radioresistance has been identified as a major cause of therapeutic failure [8-10]. Elucidation of the mechanisms underlying the radioresistance in NPC is therefore beneficial for the individualized treatment for NPC.

As a critical component in the Wnt/ $\beta$-catenin signaling pathway [11], $\beta$-catenin has been linked strongly to the prognosis of NPC [12-14]; however, some studies argued that $\beta$-catenin had no associations with survival of NPC patients [15] and did not affect the invasion and metastasis of NPC cells [16]. In addition, the Wnt/ $\beta$-catenin signaling has been found to be involved in NPC radioresistance $[17,18]$. To the best of our knowledge, however, the effect of $\beta$-catenin overexpression on radioresistance remains unknown in NPC until now.

In this study, we modeled $\beta$-catenin overexpression in a human NPC CNE- 2 cell line by transfection with the pcDNA3.1/Hygro( +$) / \beta$-catenin recombinant vector, and then examined the effects of $\beta$-catenin overexpression on the radiosensitivity of human NPC CNE- 2 cells and investigated the underlying mechanisms. We detected higher $D_{0}, D_{q}$, surviving fraction (SF), radiation sensitivity enhancement ratio (SER), viability, TCF/LEF transcriptional activity, lower apoptotic rate, down-regulation of GSK-3 $\beta$ expression and up-regulation of Cyclin D1 expression in the CNE- 2 cells overexpressing $\beta$-catenin than in negative and non-transfected controls. Our findings may provide insights into the elucidation of the mechanisms underlying the radioresistance in NPC.

\section{Materials and Methods}

Ethical statement

This study was approved by the Ethics Review Committee of Fujian Cancer Hospital (permission no. FJZLYY-201500127). Written informed consent was obtained from all participants following a detailed description of the study purpose. 


\section{Cellular Physiology Cell Physiol Biochem 2018;50:1929-1944

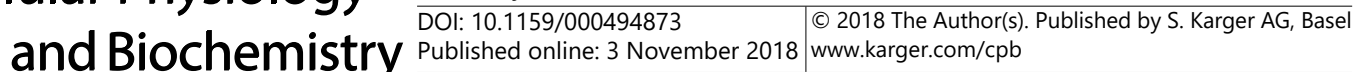

He et al.: $\beta$-Catenin Overexpression Decreases CNE-2 Cell Radiosensitivity

\section{Tissue samples}

Normal nasopharyngeal specimens and NPC specimens were obtained from Fujian Cancer Hospital (Fuzhou, China). All NPC patients were definitively diagnosed with pathological examinations.

\section{Immunohistochemistry}

Paraffin blocks that contained sufficient formalin-fixed tumor specimens were cut into $3 \mu \mathrm{m}$ sections and mounted on silane-coated slides for immunohistochemical staining analysis. Sections were then deparaffinized with dimethylbenzene and rehydrated consecutively using sequential ethanol $(100 \%, 95 \%$, $90 \%, 85 \%, 80 \%$ and $75 \%$ ). Antigen retrieval was done in $0.01 \mathrm{M}$ sodium citrate buffer (autoclaved at $121^{\circ} \mathrm{C}$ for $2 \mathrm{~min}, \mathrm{pH} \mathrm{6.0)}$ and endogenous peroxidase was blocked by incubation in $3 \% \mathrm{H}_{2} \mathrm{O}_{2}$ for 10 min at room temperature. The sections were then washed in PBS and incubated with anti- $\beta$-catenin (1:1000 dilution; Cell Signaling Technology, Inc; Danvers, MA, USA) at $4^{\circ} \mathrm{C}$ for $12 \mathrm{~h}$. Subsequently, sections were washed three times in PBS and incubated with the HRP-conjugated secondary antibody for $30 \mathrm{~min}$ at room temperature. All slides were counterstained diaminobenzidine (DAB) solution and $20 \%$ hematoxylin, and dehydrated. Slides stained the antibody diluent in the primary antibody step served as negative controls.

\section{Cell line and culture}

Human NPC CNE-2 cell line was maintained in Laboratory of Radiation Oncology and Radiobiology, Fujian Cancer Hospital (Fuzhou, China), and cultured in RPMI-1640 medium (Gibco BRL; Gaithersburg, MD, USA) supplemented with $10 \%$ fetal bovine serum (FBS: Gibco BRL; Gaithersburg, MD, USA) at $37^{\circ} \mathrm{C}$ containing $5 \% \mathrm{CO}_{2}$.

\section{Cell transfection}

CNE-2 cells were seeded onto 24 -well plates (Corning, Inc.; Corning, NY, USA) and cells growing to $80 \%$ to $90 \%$ confluence were transfected with pcDNA3.1/Hygro $(+) / \beta$-catenin recombinant vector (provided by the Laboratory of Radiation Oncology and Radiobiology, Fujian Cancer Hospital; Fuzhou, China) (transfection group)and pcDNA3.1/Hygro(+) vector (Invitrogen; San Diego, CA, USA) (negative control) using the FuGENE® HD Transfection Reagent (Promega; Madison, WI, USA), while non-transfected cells served as a blank control. Following transfection for $48 \mathrm{~h}$, cells were digested with $0.25 \%$ pancreatin (Sigma-Aldrich; St. Louis, MO, USA), re-suspended in RPMI-1640 medium containing hygromycin (Amresco, Inc.; Solon, OH, USA), and seeded onto 6-well plates (Corning, Inc.; Corning, NY, USA) for further 14-day incubation. Then, cells were harvested for the subsequent experiments.

\section{Colony-formation assay}

Log-phase CNE-2 cells in the transfection group, negative control group and the blank control group were digested with $0.25 \%$ pancreatin and then seeded onto 6-well plates (Corning, Inc.; Corning, NY, USA) at densities of 100, 200,400, 800, 1600 and 1600 cells per well, which were then exposed to 6 MV X-ray radiation using a linear accelerator (Elekta; Stockholm, Sweden) at single doses of 0, 2, 4, 6, 8 and 10 Gy with the following radiation characteristics: size of the radiation field, $30 \mathrm{~cm} \times 30 \mathrm{~cm}$; source surface distance, 100 $\mathrm{cm}$; and dose-rate, $285 \mathrm{cGy} / \mathrm{min}$. Four replicates were assigned for each radiation dose. Following radiation, cells were cultured for further 14 days, and then stained with $2 \%$ crystal violet. The number of colonies ( $\geq$ 50 cells per colony) was counted under a light microscope. The plating efficiency (PE) was calculated using the following formula: PE $(\%)=$ number of colonies/original cell-seeding density $\times 100 \%$, and the surviving fraction (SF) was estimated using the following formula: $\mathrm{SF}=$ number of colonies/(number of cells seeded $\times$ PE). The cell survival curve was plotted using the multi-target single-hit model: $\mathrm{SF}=1-\left(1-\mathrm{e}^{-D / D 0}\right)^{\mathrm{N}}$, and the radiobiological parameters $D_{0}$ (the dose that gave an average of one hit per target), $D_{\mathrm{q}}$ (quasi-threshold dose), $\mathrm{N}$ (extrapolation number) and $\mathrm{SF}_{2}$ (the $\mathrm{SF}$ following exposure to 2 Gy radiation) were determined using the survival curve. In addition, the radiation sensitivity enhancement ratio (SER) was calculated using the following formula: SER $=D_{0}$ of the blank or negative control group $/ D_{0}$ of the transfection group. All experiments were assayed in triplicate. 


\section{Cellular Physiology Cell Physiol Biochem 2018;50:1929-1944

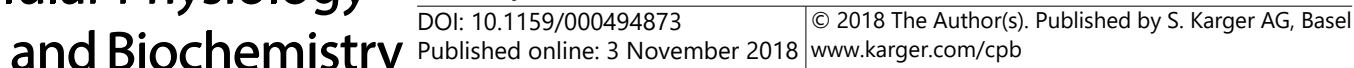

\section{Analysis of cell cycle}

Log-phase CNE-2 cells at approximately $60 \%$ confluence in the transfection group, negative control group and the blank control group were exposed to X-ray radiation at doses of 0 and 6 Gy for $24 \mathrm{~h}$, respectively. Then, cells were digested with $0.25 \%$ pancreatin, prepared into single-cell suspensions, and centrifuged at room temperature. The supernatant was discarded, and the sediment was stained with the cell cycle detection kit (BD Biosciences, San Diego, CA, USA) following the manufacturer's instructions. The cell cycle was analyzed with a FACSCanto ${ }^{\mathrm{TM}}$ II flow Cytometer (BD Biosciences; SanJose, CA, USA). All analyses were repeated in triplicate.

\section{Measurement of cell viability}

The viability of the cells was assessed by the MTT assay. Cells were seeded onto 96-well plates (Corning, Inc.; Corning, NY, USA) overnight, and then exposed to X-ray radiation at doses of 0 and 6 Gy. Following 24-h treatment, MTT ( $2 \mathrm{mg} / \mathrm{mL}$ ) was added to each well and incubated at $37^{\circ} \mathrm{C}$ for $4 \mathrm{~h}$. The, the medium was discarded, and the formed formazan crystals were dissolved in dimethyl sulfoxide (DMSO; $150 \mu \mathrm{l} /$ well). The absorbance was read at $570 \mathrm{~nm}$ using a Model 680 microplate reader (Bio-Rad Laboratory; Hercules, CA, USA). All measurements were repeated in triplicate.

\section{Detection of apoptosis}

Log-phase CNE-2 cells at approximately 60\% confluence in the transfection group, negative control group and the blank control group were exposed to X-ray radiation at doses of 0 and $6 \mathrm{~Gy}$ for $24 \mathrm{~h}$, respectively. Then, cells were digested with $0.25 \%$ pancreatin, prepared into single-cell suspensions, and centrifuged at $1200 \mathrm{r} / \mathrm{min}$ at room temperature for $5 \mathrm{~min}$. The supernatant was discarded, and the sediment was washed twice in cooled PBS, suspended in $100 \mu \mathrm{l}$ of binding buffer, and mixed evenly with $5 \mu$ l of FITC Annexin V(BD Biosciences; San Diego, CA, USA) and $5 \mu \mathrm{l}$ of propidium iodide (PI; BD Biosciences; San Diego, CA, USA) in darkness at room temperature for 15 min. Apoptosis was detected on a FACSCanto ${ }^{\mathrm{TM} I I}$ flow Cytometer (BD Biosciences; San Jose, CA, USA). All measurements were repeated in triplicate.

\section{Measurement of TCF/LEF transcriptional activity}

Log-phase CNE-2 cells in the transfection group, negative control group and the blank control group were digested with $0.25 \%$ pancreatin and centrifuged, and the supernatant was discarded. The sediment was re-suspended in Opti-MEM® I Reduced Serum Medium (Gibco; Grand Island, NY, USA) containing 10\% serum, and prepared into single-cell suspensions. Cells were then seeded onto 96-well plates (Corning, Inc.; Corning, NY, USA) at a density of $2 \times 10^{4}$ cells per well. Subsequently, cells in each group were transfected with $125 \mathrm{ng}$ TCF/LEF luciferase reporter vector (Qiagen; Hilden, Germany) and negative control vector using the FuGENE® HD Transfection Reagent, followed by exposure to X-ray radiation at a dose of 6 Gy. After $24 \mathrm{~h}$ of radiation, cells were lysed, and the firefly luciferase activity and Renilla luciferase activity were measured using the Dual Luciferase Reporter Assay System (Promega; Madison, WI, USA). The relative luciferase activities were calculated by the ratios of the firefly luciferase activity/Renilla luciferase activity in cells transfected with the TCF/LEF luciferase reporter vector to the firefly luciferase activity/Renilla luciferase activity in cells transfected with thenegative control vector. All measurements were repeated in triplicate.

Effect of X-ray radiation on the expression of key molecules of the Wnt/ $\beta$-catenin signaling pathway in CNE-2 cells

CNE-2 cells growing to approximately $50 \%$ confluence in the transfection group, negative control group and the blank control group were harvested and exposed to X-ray radiation at doses of 0 and 6 Gy for $24 \mathrm{~h}$, respectively. Then, cells were harvested, and the $\beta$-catenin, GSK-3 $\beta$ and Cyclin D1 expression was determined using Western blotting and qPCR assays.

\section{Western blotting analysis}

Cells were digested with pancreatin, harvested, lysed and centrifuged at $12000 \mathrm{r} / \mathrm{min}, 4^{\circ} \mathrm{C}$ for $5 \mathrm{~min}$. Nuclear and cytoplasm extracts were prepared using the Nuclear and Cytoplasmic Extraction Reagents according to the manufacturer's instructions (Novagen; Darmstadt, Germany). The protein concentration was qualified with a BCA Protein Assay Kit (Thermo Fisher Scientific, Inc.; Waltham, MA, USA). Total protein was separated with $10 \%$ SDS-PAGE, and electro-transferred to Nitrocellulose (NC) membranes 


\section{Cellular Physiology Cell Physiol Biochem 2018;50:1929-1944 \begin{tabular}{ll|l|l|l} 
DOI: 10.1159/000494873 & O 2018 The Author(s). Published by S. Karger AG, Basel \\
www.karger.com/cpb
\end{tabular}}

He et al.: $\beta$-Catenin Overexpression Decreases CNE-2 Cell Radiosensitivity

(GE Healthcare; Pittsburgh, PA, USA) at $100 \mathrm{~V}$ for $1.5 \mathrm{~h}$. The NC membrane was blocked with $3 \%$ bovine serum albumin (BSA; Sigma-Aldrich, St. Louis, MO, USA), washed in TTBS (20 $\mathrm{mM}$ Tris- $\mathrm{HCl}, 150 \mathrm{mM} \mathrm{NaCl}$ and $0.1 \%$ Tween-20, pH 7.2), and incubated with primary antibodies (1:1000 dilution; Cell Signaling Technology, Inc.; Danvers, MA, USA) for $4 \mathrm{~h}$, while $\beta$-actin (1:1000 dilution; Cell Signaling Technology, Inc.; Danvers, MA, USA) or lamin B1 (1:3000, Proteintech, USA) served as a loading control. Then, the blots were incubated with the HRPconjugated secondary antibody (1:5000 dilution; Thermo Fisher Scientific, Inc.; Waltham, MA, USA) for 3 h, visualized with the ECL Chemiluminescent Substrate Reagent Kit (Thermo Fisher Scientific, Inc.; Waltham, MA, USA) and analyzed with the Carestream IS4000MM Pro Molecular Imaging System (Carestream Health, Inc.; Rochester, NY, USA). The expression of the target protein was expressed as the ratio of the absorbance of the target protein band to the absorbance of the loading control band. All determinations were repeated in triplicate.

\section{qPCR assay}

Total RNA was extracted from CNE-2 cells using the TRIzol Reagent (Invitrogen; San Diego, CA, USA) and reversely transcribed into cDNA with the cDNA Reverse Transcription Kit (Thermo Fisher Scientific, Inc.; Waltham, MA, USA). The mRNA expression of the target genes was quantified using qPCR assay in a 20 $\mu \mathrm{l}$ system containing $6 \mu \mathrm{l}$ of $\mathrm{ddH}_{2} \mathrm{O}, 1 \mu \mathrm{l}$ of the forward and reverse primers (10 $\mu \mathrm{M}$ each, Table 1), $10 \mu \mathrm{l}$ of Master Mix and $2 \mu \mathrm{l}$ of cDNA template. qPCR assay was performed on a Roche LightCycler 480 real-time PCR system (Roche; Basel, Swiss) under the following conditions: at $95^{\circ} \mathrm{C}$ for $10 \mathrm{~min}$; followed by 40 cycles of at $95^{\circ} \mathrm{C}$ for $10 \mathrm{~s}$, at $60^{\circ} \mathrm{C}$ for $10 \mathrm{~s}$, and at $72^{\circ} \mathrm{C}$ for $20 \mathrm{~s}$. Following completion of the PCR assay, the program for the melting curve was recorded by holding at $95^{\circ} \mathrm{C}$ for $10 \mathrm{~s}$, at $60^{\circ} \mathrm{C}$ for $1 \mathrm{~min}$; then heating slowly until $95^{\circ} \mathrm{C}$; and finally cooling to $40^{\circ} \mathrm{C}$ for $30 \mathrm{~s}$. The relative gene expression was calculated using the $2^{-\Delta \Delta \mathrm{Ct}}$ method. All PCR assays were repeated in triplicate.

\section{Statistics}

All measurement data were expressed as mean \pm standard deviation (SD), and all statistical analyses were performed using the statistical software SPSS version 18.0 (SPSS, Inc.; Chicago, IL, USA). One-way ANOVA was used for multiple comparisons, and stepwise multiple comparisons were done with LSD test. A $P$ value of $<0.05$ was considered statistically significant.

\section{Results}

$\beta$-catenin is overexpressed in the radioresistant NPC specimens

Immunohistochemical staining revealed high $\beta$-catenin expression in radioresistant NPC specimens, and low $\beta$-catenin expression in radiosensitive NPC specimens, which was similar to that in normal nasopharyngeal specimens (Fig. 1).

\section{$\beta$-catenin is overexpressed in the transfected CNE-2 cells}

qPCR assay detected higher relative $\beta$-catenin $m R N A$ expression in the transfection group than in the blank control group $(3.89 \pm 0.27$ vs. $1.09 \pm 0.20, P<0.01)$ and negative control group (3.89 \pm 0.27 vs. $1.08 \pm 0.2, P<0.01)$, while no significant difference was seen between the blank and negative controls (1.09 \pm 0.2 vs. $1.08 \pm 0.2, P>0.05)$ (Fig. $2 \mathrm{~A}$ ). Similarly, Western blotting analysis revealed higher $\beta$-catenin protein expression in the transfection group than in the blank and negative controls $(P<0.05)$ and no significant difference between the blank and negative control groups (Fig. 2B). Taken together, our data indicate the successful modeling of $\beta$-catenin overexpression in CNE- 2 cells. 


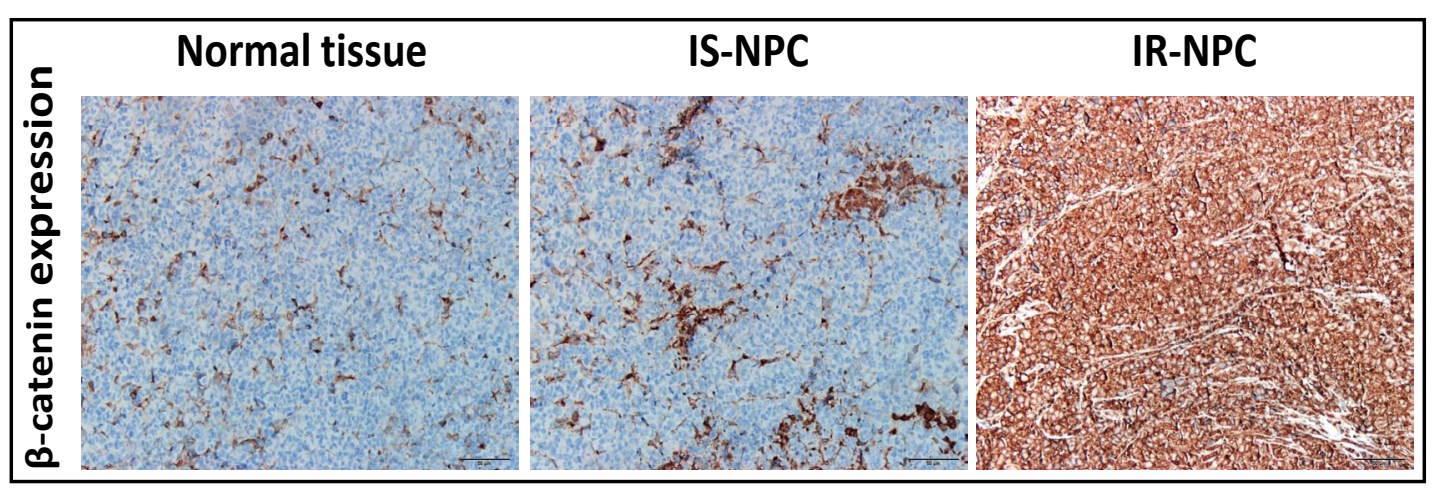

Fig. 1. Immunohistochemical staining of $\beta$-catenin expression in normal nasopharyngeal specimens and NPC specimens $(\times 20)$. Normal tissue, normal nasopharyngeal specimens; IS-NPC, radiosensitive NPC specimens; IR-NPC, radioresistant NPC specimens. Scale bar $=50 \mu \mathrm{m}$.

Fig. 2. The efficiency of $\beta$-catenin overexpression is checked. (A) qPCR assay is employed to determine $\beta$-catenin mRNA expression, while $\beta$-actin serves as an internal control. All error bars are mean \pm s.d $(\mathrm{n}=3$ independent experiments). ${ }^{*} \mathrm{P}<0.05$, ${ }^{* *} \mathrm{P}<0.01$. (B) Western blotting assay is performed to determine the $\beta$-catenin protein expression, while $\beta$-actin serves as a loading control.

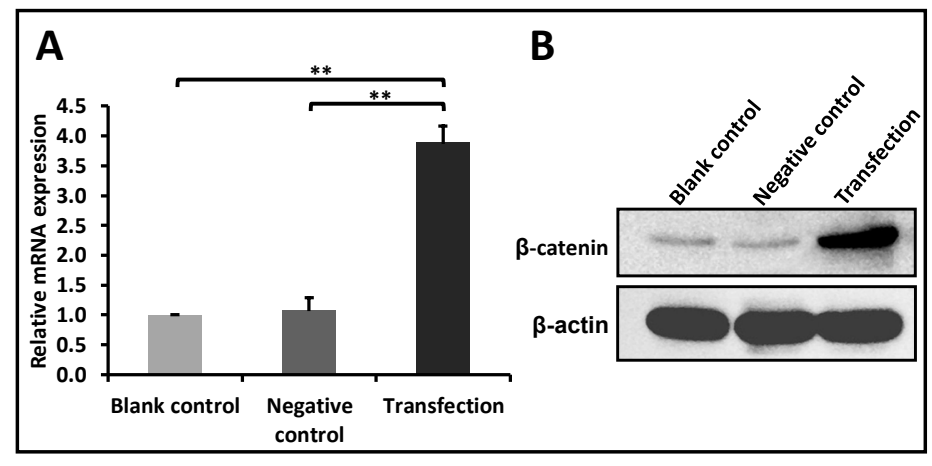

$\beta$-catenin overexpression decreases GSK-3 $\beta$ expression and increases Cyclin D1 expression following exposure to $X$-ray radiation

Following exposure to X-ray radiation at $6 \mathrm{~Gy}$ for $24 \mathrm{~h}$, the GSK-3 $\beta$ mRNA expression was lower in the transfection group than in the negative $(0.41 \% \pm 0.01 \%$ vs. $0.81 \pm 0.1 \%, P<0.05)$ and blank controls $(0.41 \% \pm 0.01 \%$ vs. $0.7 \pm 0.08 \%, P<0.01)$, and no significant difference was seen between the negative and blank controls $(0.81 \pm 0.1 \%$ vs. $0.7 \pm 0.08 \%, P>0.05)$ (Fig. $3 \mathrm{~A}$ ). In addition, higher GSK-3 $\beta$ protein expression was detected in the transfection group than in the negative and blank controls $(P<0.05)$, and no significant difference was seen between the negative and blank controls $(P>0.05)$ (Fig. 3B and 3C).

Following exposure to X-ray radiation at 6 Gy for $24 \mathrm{~h}$, the Cyclin D1 mRNA expression was higher in the transfection group than in the negative $(2.96 \% \pm 0.6 \%$ vs. $1.23 \pm 0.03 \%, P<$ $0.01)$ and blank controls $(2.96 \% \pm 0.6 \%$ vs. $1.11 \pm 0.3 \%, P<0.01)$, and no significant difference was seen between the negative and blank controls $(P>0.05)$ (Fig. 3A). Additionally, higher Cyclin D1 protein expression was detected in the transfection group than in the negative and blank controls $(P<0.05)$, and no significant difference was seen between the negative and blank controls $(P>0.05)$ (Fig. 3B and 3C).

\section{$\beta$-catenin overexpression decreases the radiosensitivity of CNE-2 cells}

There was an increase in $D_{0}$ and $D_{\mathrm{q}}$ in the transfection group relative to the negative and blank control groups (Table 2), indicating a reduction in the radiosensitivity in the transfection group as compared to the negative and blank controls. Following exposure to radiation at doses of 2 to $10 \mathrm{~Gy}$, significantly higher SF values were estimated in the transfection group than in the blank control and negative control groups $(P<0.05)$, while no significant differences were found between the blank and negative controls $(P>0.05)$ (Fig. 4). In addition, the SER in the transfection group was 0.75 -fold and 0.68 -fold changes from the blank and negative control groups, respectively (Table 2). 


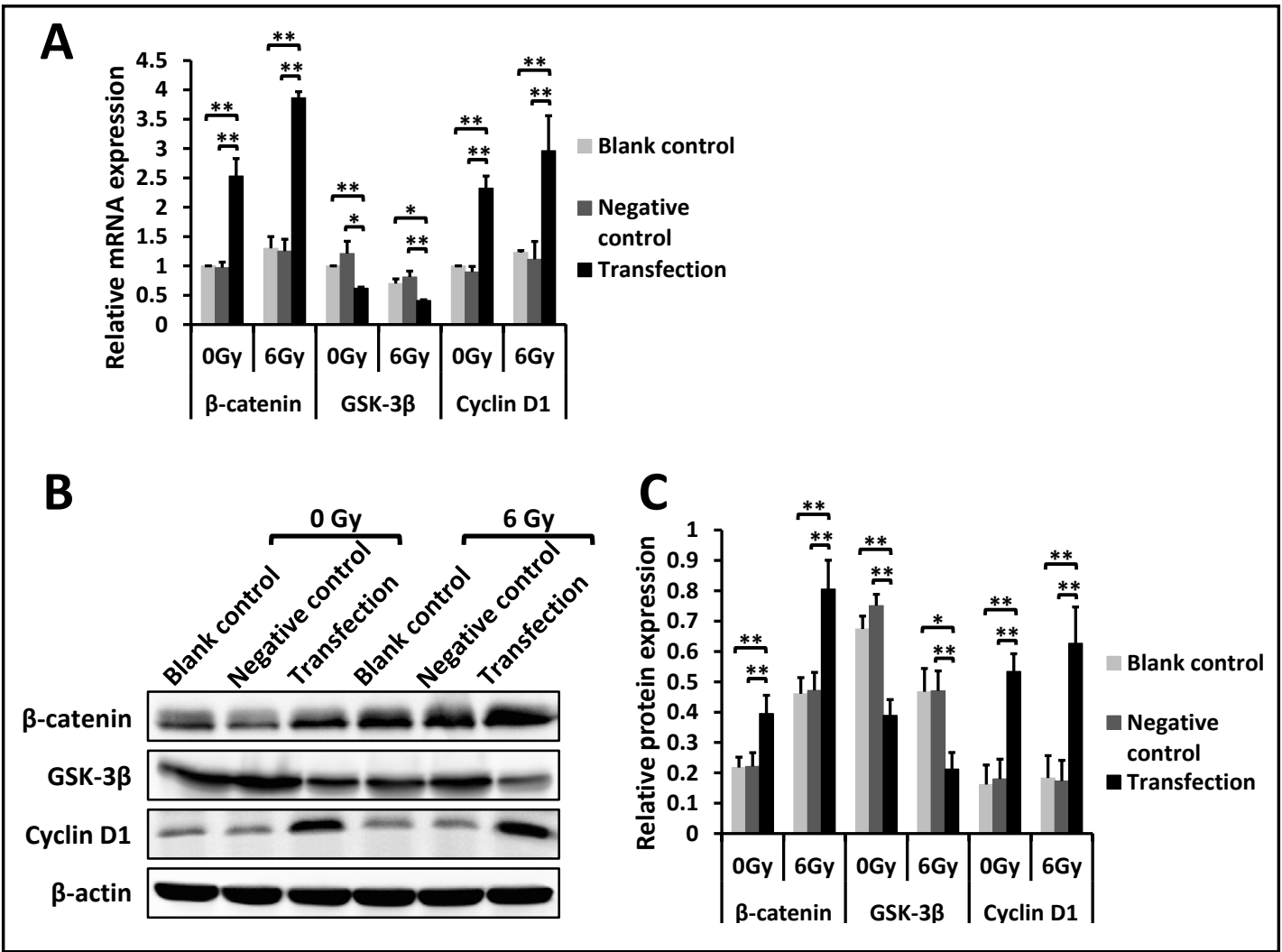

Fig. 3. $\beta$-catenin overexpression decreases GSK-3 $\beta$ expression and increases Cyclin D1 expression following exposure to X-ray radiation. (A) The $\beta$-catenin, GSK-3 $\beta$ and Cyclin D1 mRNA expression is quantified using qPCR assay in the transfection group, negative control group and the blank control group pre- and postexposure to X-ray radiation at a dose of $6 \mathrm{~Gy}$ for $24 \mathrm{~h}$, while $\beta$-actin serves as an internal control. All error bars are mean \pm s.d. $\mathrm{n}=3$ independent experiments. ${ }^{*} \mathrm{P}<0.05,{ }^{* *} \mathrm{P}<0.01$. $(\mathrm{B}, \mathrm{C})$ Western blotting assay is performed to determine the $\beta$-catenin, GSK-3 $\beta$ and Cyclin D1 protein expression in the transfection group, negative control group and the blank control group cells pre- and post-exposure to X-ray radiation at a dose of 6 Gy for $24 \mathrm{~h}$, while $\beta$-actin serves as an internal control. All error bars are mean \pm SD $(n=3$ independent experiments). ${ }^{*} \mathrm{P}<0.05,{ }^{* *} \mathrm{P}<0.01$.

$X$-ray radiation reduces the proportion of $\beta$-catenin overexpressed CNE-2 cells in $G 2 / M$ phase of the cell cycle

Prior to X-ray radiation, there were no significant differences among the transfection, negative control and blank control groups in terms of the proportions of CNE-2 cells in the G0/ $\mathrm{G} 1, \mathrm{~S}$ or $\mathrm{G} 2 / \mathrm{M}$ phase of the cell cycle $(P$ $>0.05)$. After $24 \mathrm{~h}$ of X-ray radiation at a dose of $6 \mathrm{~Gy}$, the proportion of CNE-2 cells in the G2/M phase was significantly lower in the transfection group than in the blank control group $(17.83 \% \pm 3.97 \%$ vs. 36.21 $\pm 8.38 \%, P<0.05)$ and negative control group $(17.83 \% \pm 3.97 \%$ vs. $39.54 \pm 12.07 \%, P<$ $0.05)$, and no significant difference was observed between the blank control group and the negative control group $(36.21 \pm 8.38 \%$ vs. $39.54 \pm 12.07 \%, P>0.05)$. In addition, the proportion of CNE- 2 cells in the G0/G1 phase was greater in the transfection group than
Table 2. The radiobiological parameters of CNE-2 cells exposed to X-ray radiation. N, extrapolation number; $\mathrm{b}$, $\mathrm{D}_{0}$ of the blank control/ $\mathrm{D}_{0}$ of the negative control; $\mathrm{c}, \mathrm{D}_{0}$ of the blank control group $/ \mathrm{D}_{0}$ of the transfection group; $d, D_{0}$ of the negative control group $/ \mathrm{D}_{0}$ of the transfection group

\begin{tabular}{lccccc}
\hline Group & $\mathrm{D}_{0}(\mathrm{~Gy})$ & $\mathrm{D}_{\mathrm{q}}(\mathrm{Gy})$ & $\mathrm{Na}^{\mathrm{a}}$ & $\mathrm{SF}_{2}$ & $\mathrm{SER}$ \\
\hline Blank control & 1.44 & 2.49 & 1.73 & 0.34 & - \\
Negative control & 1.31 & 2.71 & 2.06 & 0.28 & $1.09^{\mathrm{b}}$ \\
Transfection & 1.93 & 3.17 & 1.62 & 0.58 & $0.75^{\mathrm{c}} / 0.68^{\mathrm{d}}$ \\
\hline
\end{tabular}

\section{KARGER}


in the negative control group $(50.34$ $\pm 3.42 \%$ vs. $28.2 \pm 8.46 \%, P<0.05$ ), while no significant differences were detected between the blank control group and the transfection group or the negative control group $(P>$ 0.05 ). In terms of the proportion of CNE- 2 cells in the $S$ phase of the cell cycle, no significant difference was found among the three groups $(P>$ 0.05) (Table 3, Fig. 5).

\section{$\beta$-catenin overexpression promotes viability of CNE- 2 cells post-radiation}

There was no significant difference in the viability of cells among the transfection group (108 $\pm 5.00 \%$ ), negative control group $(101.33 \pm 8.08 \%)$ and the blank control group $(100 \pm 5.00 \%)$ prior to X-ray radiation $(P>0.05)$, and the viability of cells was significantly higher in the transfection group than in the negative control group $(96 \% \pm 8.72 \%$ vs. $74.67 \pm 7.05 \%, P$ $<0.05$ ) and the blank control group $(96 \% \pm 8.72 \%$ vs. $75.33 \pm 7.02 \%, P$ $<0.05$ ) $24 \mathrm{~h}$ post-exposure to $6 \mathrm{~Gy}$ X-ray radiation (Fig. 6).

$X$-ray radiation reduces the apoptosis of CNE-2 cells overexpressing $\beta$-catenin

There was no significant difference in the apoptosis rate of CNE- 2 cells among the transfection group $(8.57 \pm 0.38 \%)$, negative control group $(8.4 \pm 1.35 \%)$ and the blank control group (10.8 \pm $2.51 \%)$ prior to X-ray radiation $(P$ $>0.05$ ), and the apoptosis rate of CNE-2 cells was significantly lower in the transfection group than in the negative control group $(8.37 \%$ $\pm 1.97 \%$ vs. $14.9 \pm 4.08 \%, P<0.05)$ and the blank control group $(8.37 \% \pm 1.97 \%$ vs. $14.13 \pm 1.76 \%, P<0.05) 24$ h post-exposure to 6 Gy X-ray radiation $(P<0.05)$ (Fig. $7 \mathrm{~A}$ and $7 \mathrm{~B})$.

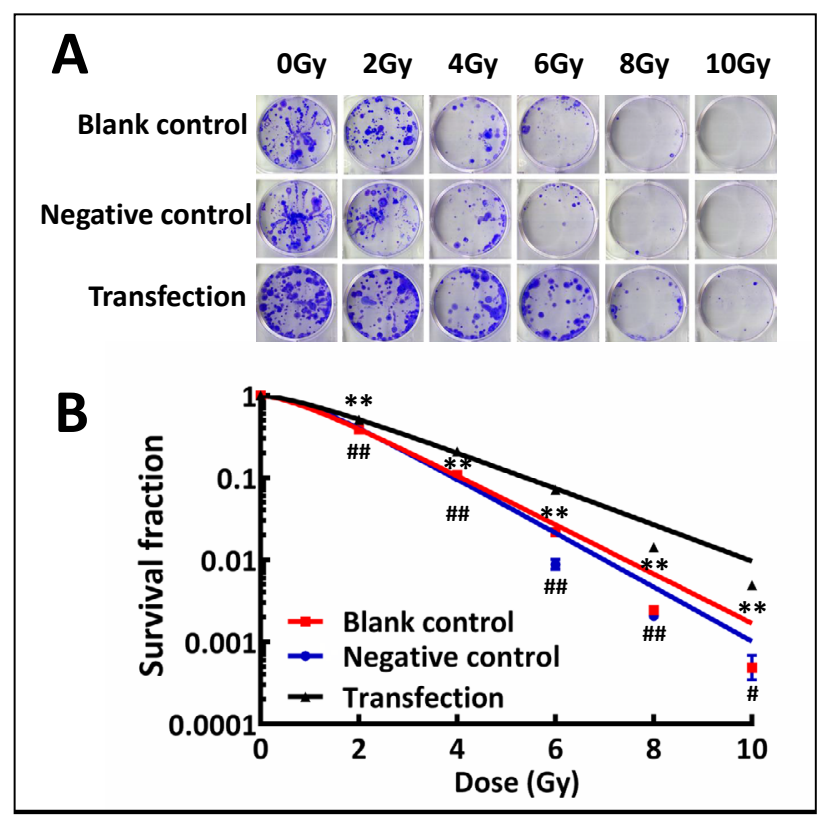

Fig. 4. $\beta$-catenin overexpression decreases the radiosensitivity of $\mathrm{CNE}-2$ cells. (A) Colony-formation assay is performed in the transfection group, blank control group and negative control group upon exposure to X-ray radiation at doses of 0, 2, 4, 6, 8 and 10 Gy. (B) Surviving fraction in the transfection group, negative control group and blank control group following exposure to X-ray radiation at doses of 0,2 , 4, 6, 8 and 10 Gy. Significantly higher SF values are found in the transfection group than in the negative control and blank control groups $(\mathrm{P}<0.05)$, while no significant differences were found between the negative and blank controls ( $\mathrm{P}$ $>0.05) .{ }^{*} \mathrm{P}<0.05,{ }^{*} \mathrm{P}<0.01$, the blank control group was compared with the transfection group. ${ }^{\#} \mathrm{P}<0.05$, ${ }^{\# \#} \mathrm{P}<0.01$, the negative control group vs. the transfection group.

Table 3. Proportions of CNE-2 cells in the G0/G1, S or G2/M phase of the cell cycle pre- and post-exposure to X-ray radiation

\begin{tabular}{lcccc}
\hline Dose of X-ray radiation & Group & G0/G1 phase & S phase & G2/M phase \\
\hline \multirow{4}{*}{0} & Blank control & $65.76 \pm 5.34$ & $31.65 \pm 11.95$ & $2.59 \pm 0.49$ \\
& Negative control & $63.67 \pm 6.89$ & $33.38 \pm 7.9$ & $2.95 \pm 1.14$ \\
& Transfection & $65.21 \pm 13.04$ & $30.77 \pm 5.71$ & $4.02 \pm 1.32$ \\
& Blank control & $39.60 \pm 13.97$ & $24.19 \pm 8.86$ & $36.21 \pm 8.38$ \\
6 & Negative control & $28.2 \pm 8.46$ & $32.14 \pm 22.64$ & $39.54 \pm 12.07$ \\
& Transfection & $50.34 \pm 3.42$ & $31.83 \pm 0.9$ & $17.83 \pm 3.97$ \\
\hline
\end{tabular}




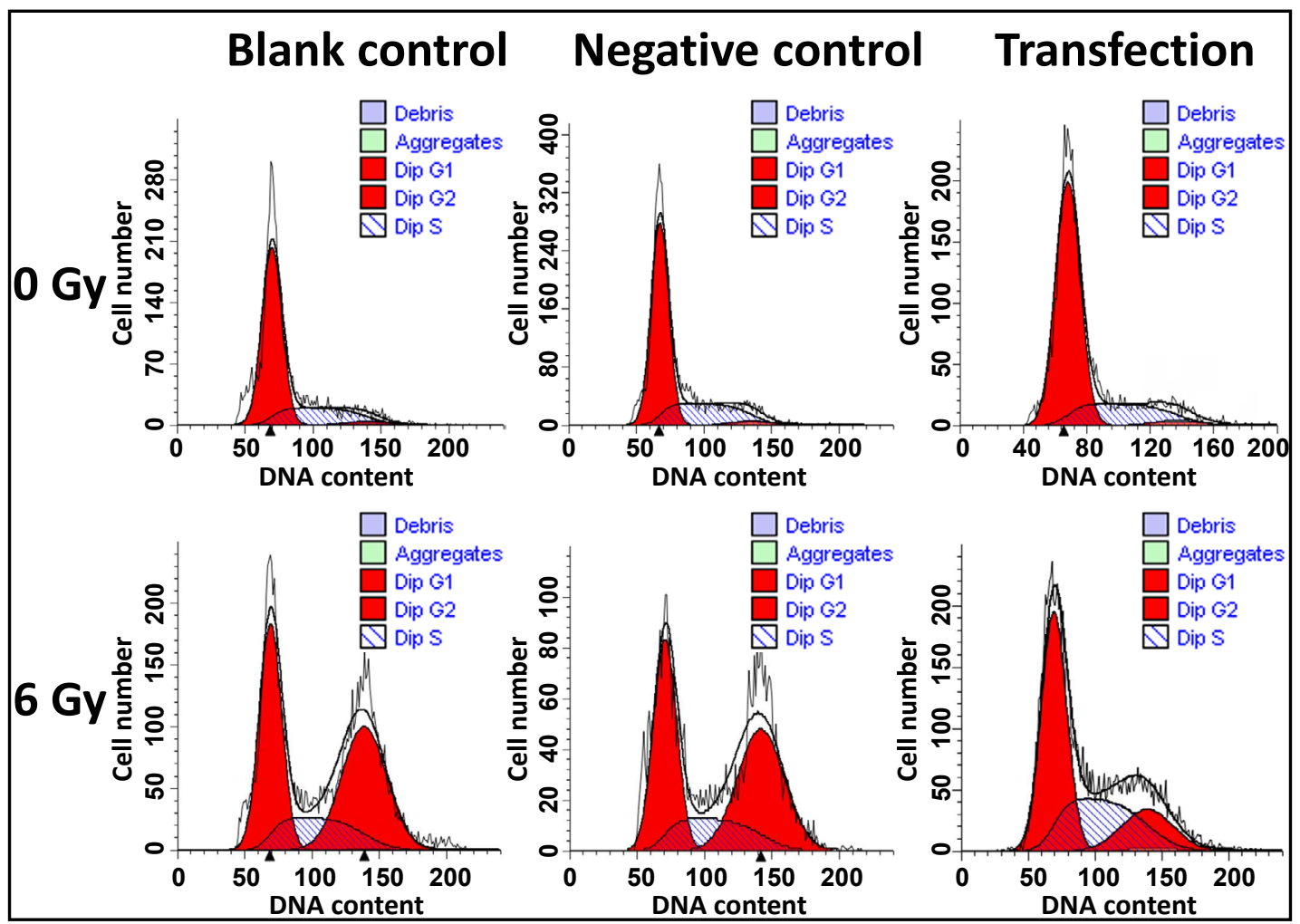

Fig. 5. $\beta$-catenin overexpression reduces G2/M arrest of CNE-2 cells induced by X-ray radiation. NPC cells are exposed to X-ray radiation at a dose of $6 \mathrm{~Gy}$ for $24 \mathrm{~h}$, and then the cell cycle distribution is examined using flow cytometry. Each experiment is repeated in triplicate.

Fig. 6. The viability of CNE2 cells was assessed by MTT assay. Cells in the transfection, blank control and negative control groups are subjected to the MTT assay. * $\mathrm{P}<0.05$ vs. the blank control and negative control groups. All measurements are repeated in triplicate. All error bars are mean \pm SD $(n=3$ independent experiments).

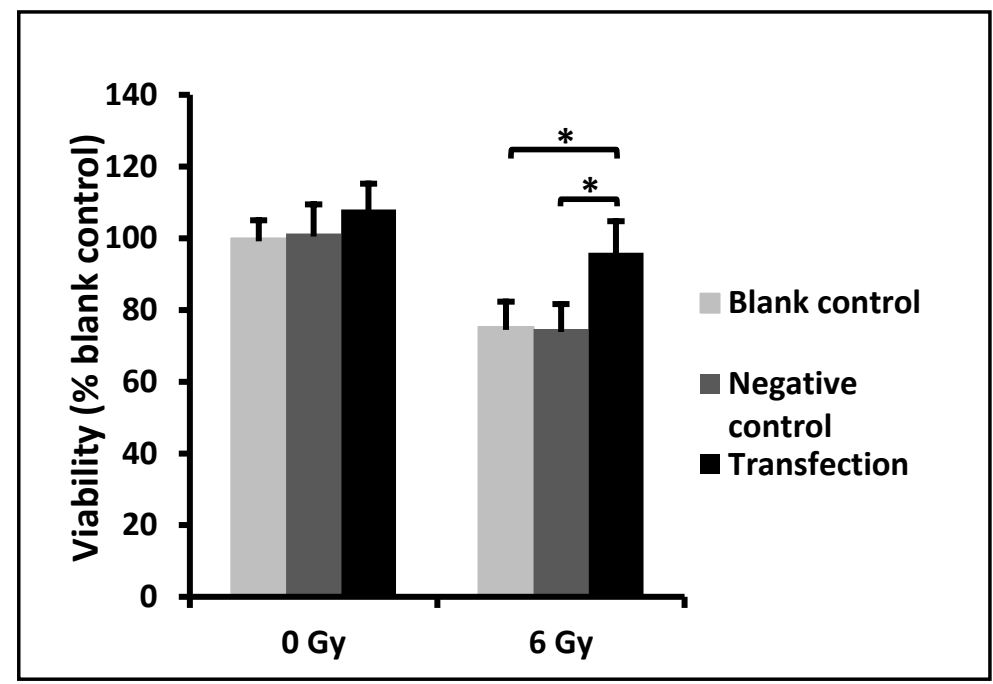

X-ray Radiation Increases the TCF/LEF Transcriptional Activity of CNE-2 Cells Overexpressing $\beta$-catenin

Prior to X-ray radiation, the TCF/LEF transcriptional activity was significantly higher in the transfection group than in the blank control group $(8.79 \% \pm 0.89 \%$ vs. $0.94 \pm 0.22 \%, P$ $<0.01)$ and the negative control group $(8.79 \% \pm 0.89 \%$ vs. $1.09 \pm 0.6 \%, P<0.01)$, while no significant difference was observed between the blank control and negative control $0.94 \%$ $\pm 0.22 \%$ vs. $1.09 \% \pm 0.6 \%, P>0.05$ ). Following exposure to 6 Gy X-ray radiation, the TCF/ LEF transcriptional activity was significantly higher in the transfection group than in the 


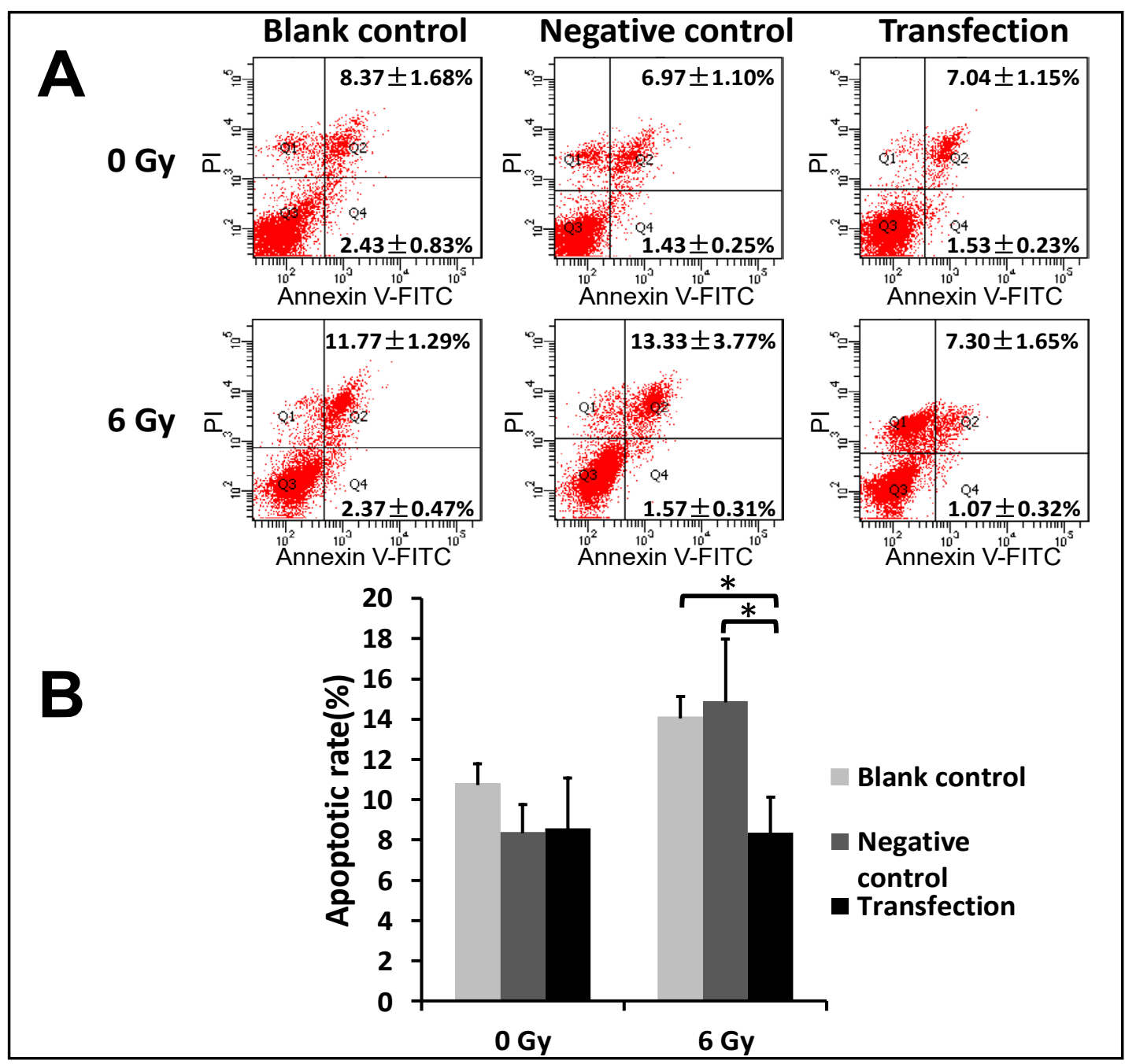

Fig. 7. $\beta$-catenin overexpression decreases the apoptotic rate of CNE- 2 cells induced by X-ray radiation. (A) NPC CNE- 2 cells are exposed to X-ray radiation at a dose of 6 Gy for $48 \mathrm{~h}$. Then, cells are stained with Annexin V-FITC and propidium iodide and analyzed using flow cytometry. Each experiment is repeated in triplicate. (B) Histogram shows the total apoptotic rate (late +early phase) of NPC cells. All error bars are mean \pm SD ( $\mathrm{n}=3$ independent experiments). ${ }^{*} \mathrm{P}<0.05$.

blank control group $(13.05 \% \pm 0.71 \%$ vs. $0.88 \pm 0.11 \%, P<0.01)$ and the negative control group $(13.05 \% \pm 0.71 \%$ vs. $1.12 \pm 0.32 \%, P<0.01)$, while no significant difference was found between the blank control and negative control $(0.88 \% \pm 0.11 \%$ vs. $1.12 \% \pm 0.32 \%, P>0.05)$. In addition, TCF/LEF transcriptional activity was significantly higher in the transfection group post-radiation relative to prior to radiation at a dose of 6 Gy $(P<0.05)$ (Fig. 8A).

To investigate the nuclear accumulation of $\beta$-catenin in the transfection group, NPC cells were exposed to 6 Gy X-ray radiation for $24 \mathrm{~h}$, and then, nuclear and cytoplasmic fractions were isolated. Each fraction was examined by Western blotting. Western blotting analysis revealed significantly higher cytoplasmic $\beta$-catenin expression in the transfection group than in the negative $(0.65 \pm 0.036$ vs. $0.4 \pm 0.017, P<0.01)$ and blank control groups $(0.65 \pm 0.036$ vs. $0.39 \pm 0.025, P<0.01)$, and no significant difference was seen between the negative and blank controls $(0.4 \pm 0.017$ vs. $0.39 \pm 0.025, P>0.05)$. Following exposure to $\mathrm{X}$-ray radiation at $6 \mathrm{~Gy}$ for $24 \mathrm{~h}$, higher nuclear $\beta$-catenin expression was detected in the transfection group than in the negative $(0.77 \pm 0.028$ vs. $0.58 \pm 0.04, P<0.01)$ and blank controls $(0.77 \pm 0.028$ vs. $0.59 \pm 0.043, P<0.01)$, and no significant difference was seen between the negative and 


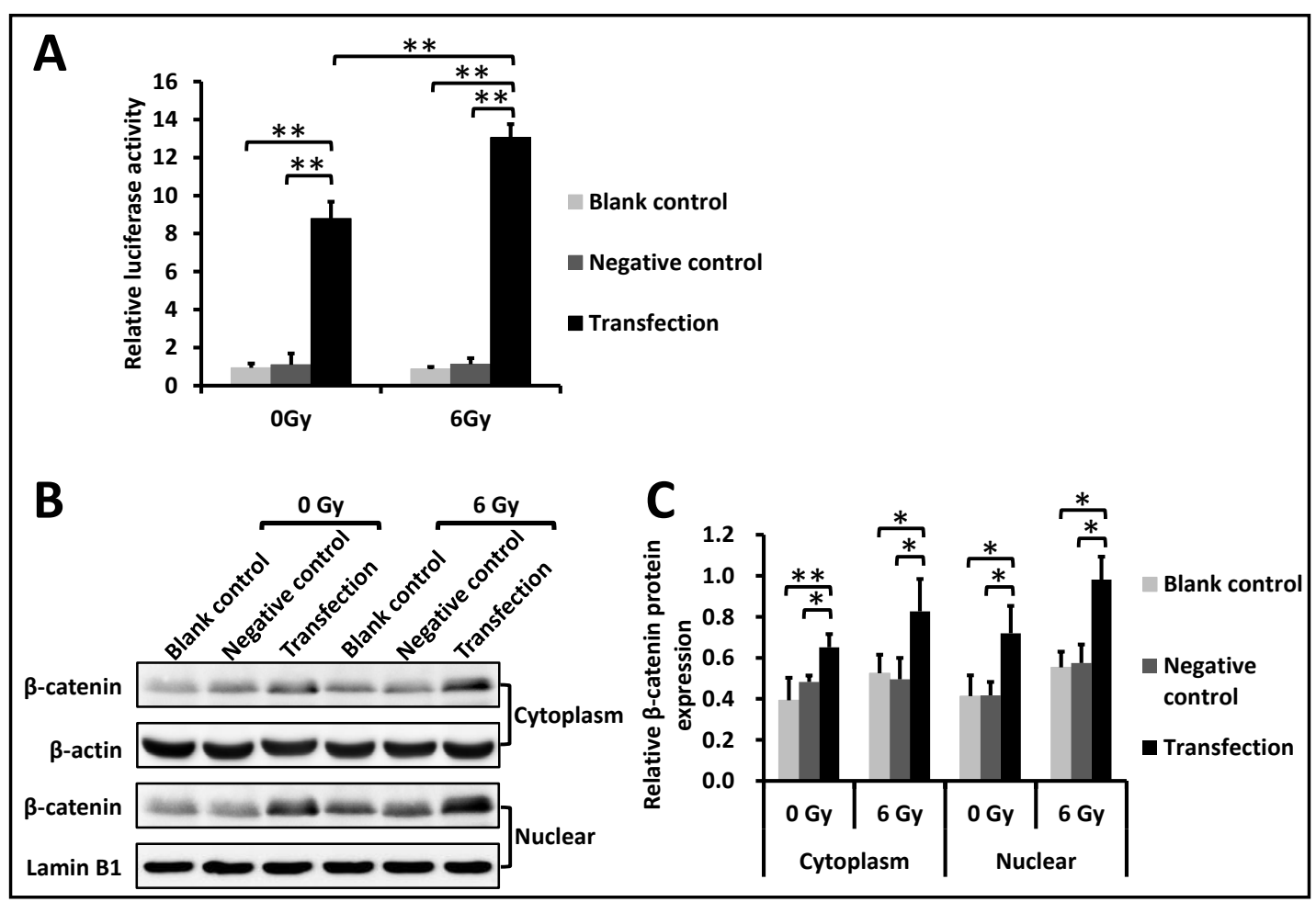

Fig. 8. Effect of $\beta$-catenin overexpression on TCF/LEF transcriptional activity and $\beta$-catenin accumulation in CNE-2 cells. (A) Following 6 Gy X-ray radiation for $24 \mathrm{~h}$, the TCF/LEF transcriptional activity is measured. All error bars are mean \pm SD ( $n=3$ independent experiments). ${ }^{* *} \mathrm{P}<0.01$. $(\mathrm{B}, \mathrm{C})$ Western blotting assay is performed to determine the cytoplasmic and nuclear $\beta$-catenin protein expression pre- and post-exposure to X-ray radiation at a dose of $6 \mathrm{~Gy}$ for $24 \mathrm{~h}$, and $\beta$-actin (for cytoplasmic protein) and Lamin B1 (for nuclear protein) serve as loading controls. ${ }^{*} \mathrm{P}<0.05$, ${ }^{* *} \mathrm{P}<0.01$.

blank controls $(0.58 \pm 0.04$ vs. $0.59 \pm 0.043, P>0.05)$. In addition, the nuclear $\beta$-catenin accumulation was higher in the transfection group post-radiation than pre-radiation $(P<$ 0.05) (Fig. 8B and 8C).

\section{Discussion}

Currently, radiotherapy is the first therapeutic option for NPC [6]. With the great advances in imaging and radiotherapy techniques, a clear-cut reduction is seen in the local recurrent rate and distal metastatic rate in NPC patients after radiotherapy [19]. Notably, following the introduction of intensity-modulated radiotherapy techniques [20-22], a 3-year local recurrence-free survival rate of over $90 \%$ and a 3-year distal metastasis-free rate of more than $80 \%$ are achieved; however, there are still patients developing regional recurrence and distal metastasis [23-25]. Radioresistance has been identified as a major factor restricting the therapeutic efficacy of NPC [26]. Elucidation of the mechanisms of radioresistance is therefore of great value to improve the therapeutic efficacy of NPC.

It has been shown that the $\mathrm{Wnt} / \beta$-catenin signaling pathway is strongly associated with the development and progression of multiple human cancers [27-32]. $\beta$-catenin, a critical component of the Wnt/ $\beta$-catenin signaling pathway [11], has been found to contribute to the radiosensitivity of cancers $[18,33]$. siRNA-induced knockdown of $\beta$-catenin expression was found to enhance the radiation sensitivity in head and neck cancerAMC-HN-9 cells [34, 35], and treatment with BC-23 (C21H14ClN304S), a novel inhibitor of $\beta$-catenin/T-cell factor 4 (Tcf4) interaction, was reported to enhance the radiation sensitivity in human p53-null non-

\section{KARGER}




\section{Cellular Physiology Cell Physiol Biochem 2018;50:1929-1944

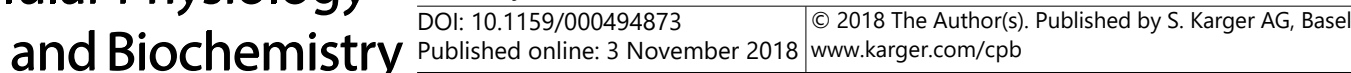 \\ He et al.: $\beta$-Catenin Overexpression Decreases CNE-2 Cell Radiosensitivity}

small cell lung cancer (NSCLC) H1299 cells [36]. Although the Wnt/ $\beta$-catenin signaling has been linked to the radiation resistance in NPC $[17,18]$, there is no knowledge regarding the effect of $\beta$-catenin overexpression on radiation resistance in NPC to date. In addition, the associations of $\beta$-catenin expression with the biological behaviors of NPC cells and the prognosis of NPC patients remain controversial until now [12-16].

To examine the correlation between $\beta$-catenin and radiation sensitivity in NPC, a human NPC CNE- 2 cell line overexpressing $\beta$-catenin was modeled with the pcDNA3.1/Hygro(+) vector in this study, which overexpressed the target gene and contained hygromycinresistant genes. By adding hygromycin into the culture of transfected CNE- 2 cells, the CNE-2 cells with failure in transfection of the pcDNA3.1/Hygro(+)/ $\beta$-catenin recombinant vector died because of intolerance to hygromycin, while the successfully transfected cells that expressed hygromycin-resistant genes survived due to tolerance to hygromycin. After continuous passaging, a single cell clone that was resistant to hygromycin and overexpressed $\beta$-catenin was yielded. Western blotting and qPCR assays determined up-regulation of $\beta$-catenin expression in CNE- 2 cells transfected with the pcDNA3.1/Hygro $(+) / \beta$-catenin vector, indicating the successful modeling of the CNE- 2 cell line overexpressing $\beta$-catenin.

It is considered that X-ray radiation induces DNA damage in cancer cells, and DNA damage results in cell cycle arrest, which then initiates the DNA repair system of cancer cells; if the cellular repair system is insufficient to complete DNA repair, cells will progress towards apoptosis [37]. Intrinsic cellular radiosensitivity has been shown to strongly correlate with radiation-induced cell cycle distribution, DNA damage repair and apoptosis [38], and a stronger ability of DNA damage repair indicates lower radiation sensitivity [39]. In the present study, colony-formation assay revealed higher $D_{0}, D_{\mathrm{q}}$ and SF values in the transfection group than in the negative and blank control groups following radiation at each dose, and the SER in the transfection group was 0.75 -fold and 0.68 -fold greater than that in the blank and negative control groups, respectively, indicating that $\beta$-catenin overexpression reduced the radiation sensitivity in CNE- 2 cells. It is reported that an increase in the ability of DNA repair results in radiation resistance and severely limits the efficacy of radiotherapy [40]. In this study, an increase was seen in $D_{\mathrm{q}}$ in $\beta$-catenin overexpressed CNE- 2 cells, as revealed by the cell survival curve, indicating the enhanced ability in the repair of sublethal cellular damages, and this may be associated with the overexpression of $\beta$-catenin. It was found that activation of the $\beta$-catenin pathway effectively promoted the repair of DNA double strand breaks (DSBs) in irradiated osteoblasts [41], and up-regulation of $\beta$-catenin expression increased the capacity of DSB repair in cancer cells [42].It is therefore considered that the role of $\beta$-catenin in DNA damage repair may be a factor affecting cellular radiation sensitivity.

Cell-cycle regulation is an important mechanism affecting radiation sensitivity [43]. Following radiation-induced DNA damages, DNA damage-related genes trigger the mechanism of cell-cycle regulation, and allow the cell cycle arrest at G1/S and G2/M checkpoints, resulting in cell cycle arrest at G1 and G2 phases [44]. Since the G1/S checkpoint is deficient in most types of cancer cells, the G2/M checkpoint arrest is a major determinant governing the radiation sensitivity in cancer cells [45]. In the cell cycle, cells in the $\mathrm{G} 2 / \mathrm{M}$ phase are most sensitive to radiation, and a reduction in the proportion of cells at the G2/M phase indicates the insensitivity to radiation [44]. In the current study, our data showed a decrease in the proportion of CNE-2 cells at the G2/M phase of the cell cycle in the transfection group relative to the blank and negative control groups $24 \mathrm{~h}$ post-exposure to X-ray radiation, suggesting the relief of the cell cycle arrest at the G2/M phase, and the reduction in the proportion of CNE-2 cells at the G2/M phase resulted in relative radiation resistance in CNE- 2 cells overexpressing $\beta$-catenin. Inhibition of $\beta$-catenin expression was found to significantly increase the proportion of hepatocellular carcinoma stem cells in the G2/M phase [45], and treatment with polyphyllin I (PPI), a major active constituent extracted from Paris polyphyllin, caused down-regulation of $\beta$-catenin expression in multiple myeloma cells and cell cycle arrest at G2/M phase [46]. These findings demonstrate the close correlation between $\beta$-catenin and cell cycle. Cyclin D1, an important cell cycle-related 


\section{Cellular Physiology Cell Physiol Biochem 2018;50:1929-1944

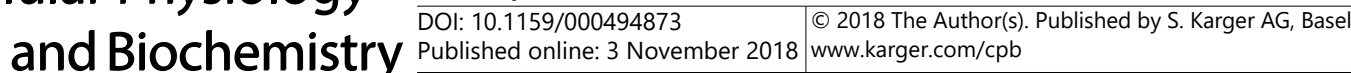 \\ He et al.: $\beta$-Catenin Overexpression Decreases CNE-2 Cell Radiosensitivity}

molecule, is involved in the regulation of cell cycle checkpoints [47]. Cyclin D1 expression has been found to strongly correlate with cancer radiosensitivity and inhibition of $\beta$-catenin and Cyclin D1 expression was reported to result in enhanced sensitivity to radiation $[48,49]$. Our findings showed up-regulation of Cyclin D1 expression in CNE-2 cells overexpressing $\beta$-catenin. It is therefore hypothesized that the effect of $\beta$-catenin on the sensitivity of CNE- 2 cells to X-ray radiation may be associated with mediating the expression of its downstream gene Cyclin D1; however, the exact mechanisms require further investigations.

To date, there is no consensus on the correlation between apoptosis and radiation sensitivity [50]. It is reported that radiation mainly leads to programmed cell death [51], and apoptosis, a form of cell death [52], may occur after programmed cell death and have no associations with cell survival [51]. It is therefore considered that apoptosis does not correlate with radiation sensitivity [51]. In another study, however, ionizing radiation was found to induce apoptosis of the human osteosarcoma SAOS-2 cells that were deficient in the expression of the product of the retinoblastoma tumor suppressor gene (pRb), while SAOS-2 derivatives expressing wild-type $\mathrm{pRb}$ exhibited increased viability and decreased apoptosis post-exposure to radiation [53]. $\beta$-catenin has been linked to apoptosis in cancer cells [54]. siRNA-mediated knockdown of $\beta$-catenin was found to inhibit the proliferation and invasion and induce apoptosis of the colon cancer SW480 cells [55], and blocking the T-cell factor (Tcf)/ $\beta$-catenin complex was reported to suppress the $\mathrm{Wnt} /$ beta-catenin signaling pathway in adrenocortical tumor cells triggering increased apoptosis [56]. In the present study, the apoptotic rate of CNE- 2 cells was significantly lower in the transfection group than in the negative and blank control groups post-radiation, and $\beta$-catenin overexpression led to downregulation of GSK-3 $\beta$, a major component of the Wnt/ $\beta$-catenin signaling pathway. Since down-regulation or inactivation of GSK-3 $\beta$, an important apoptosis-related molecule, may inhibit apoptosis, it is therefore assumed that $\beta$-catenin may affect the radiation sensitivity in NPC through mediating other Wnt/ $\beta$-catenin signaling pathway molecules.

In the classical Wnt signaling pathway, $\beta$-catenin translocates to the nucleus and binds with the downstream transcriptional factors TCF/LEF to form the transcriptional complex, thereby activating the TCF/LEF transcriptional activity [57]. In this study, our findings showed that the TCF/LEF transcriptional activity was significantly higher in the transfection group than in the blank and negative control groups, indicating that $\beta$-catenin overexpression increased the TCF/LEF transcriptional activation. In addition, 6 Gy X-ray radiation elevated the TCF/LEF transcriptional activity relative to 0 Gy radiation, which may be associated with the nuclear localization and accumulation of $\beta$-catenin caused by ionizing radiation and the resulting activation of the downstream transcriptional factors TCF/LEF [58]. To test this hypothesis, the $\beta$-catenin protein expression was determined in the cytoplasm and nucleus of CNE-2 cells, and Western blotting analysis revealed an increase in the nuclear accumulation of $\beta$-catenin in the transfection and negative control groups. In a recent study, ionizing radiation was found to induce nuclear translocation and accumulation of $\beta$-catenin and enhance the TCF/LEF transcriptional activities in glioblastoma U87 cells, and degrading $\beta$-catenin significantly reduced cell invasion [59], which is in agreement with our findings.

\section{Conclusion}

The results of the present study demonstrate that $\beta$-catenin overexpression may decrease the radiation sensitivity and lead to radiation resistance in human NPC CNE- 2 cells through up-regulating intracellular $\beta$-catenin expression and the resultant nuclear translocation and accumulation of $\beta$-catenin, thereby up-regulating Cyclin D1 and down-regulating GSK$3 \beta$ expression, activating TCF/LEF transcriptional activities, promoting the relief of the cell cycle arrest at the G2/M phase and decreasing the ability to induce apoptosis. 


\section{Cellular Physiology Cell Physiol Biochem 2018;50:1929-1944

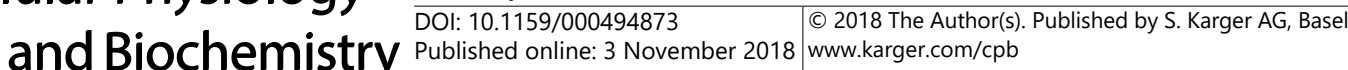

He et al.: $\beta$-Catenin Overexpression Decreases CNE-2 Cell Radiosensitivity

\section{Acknowledgements}

This study was supported by the Natural Science Foundation of Fujian Province (grant no. 2014J01299 and 2018J01732), Fujian Provincial Key Sci \& Tech Project (grant no. 2014Y0014), the grant from the National Natural Science Foundation of China (grant no. 81472907 and 81341131) and National Key Clinical Specialty Construction Project of China (grant no. 2013-554).

\section{Disclosure Statement}

The authors declare that they have no competing interests.

\section{References}

1 Chan AT, Teo PM, Johnson PJ: Nasopharyngeal carcinoma. Ann Oncol 2002;13:1007-1015.

$>2$ Wei WI, Sham JS: Nasopharyngeal carcinoma. Lancet 2005;365:2041-2054.

- 3 Tang LL, Chen WQ, Xue WQ He YQ Zheng RS, Zeng YX, Jia WH: Global trends in incidence and mortality of nasopharyngeal carcinoma. Cancer Lett 2016;374:22-30.

4 Wei KR, Zheng RS, Zhang SW, Liang ZH, Li ZM, Chen WQ: Nasopharyngeal carcinoma incidence and mortality in China, 2013. Chin J Cancer 2017;36:90.

$>5$ Chua MLK, Wee JTS, Hui EP, Chan ATC: Nasopharyngeal carcinoma. Lancet 2016;387:1012-1024.

-6 Caponigro F, Longo F, Ionna F, Perri F: Treatment approaches to nasopharyngeal carcinoma: a review. Anticancer Drugs 2010;21:471-477.

7 Zhang L, Chen QY, Liu H, Tang LQ, Mai HQ: Emerging treatment options for nasopharyngeal carcinoma. Drug Des DevelTher 2013;7:37-52.

-8 Li G, Liu Y, Liu C, Su Z, Ren S, Wang Y, Deng T, Huang D, Tian Y, Qiu Y: Genome-wide analyses of long noncoding RNA expression profiles correlated with radioresistance in nasopharyngeal carcinoma via nextgeneration deep sequencing. BMC Cancer 2016;16:719.

-9 Zhang L, Su B, Sun W, Li W, Luo M, Liu D, Mei Q, Long G, Hu G, Hu G: Twist1 promotes radioresistance in nasopharyngeal carcinoma. Oncotarget 2016;7:81332-81340.

10 Li G, Qiu Y, Su Z, Ren S, Liu C, Tian Y, Liu Y: Genome-wide analyses of radioresistance-associated miRNA expression profile in nasopharyngeal carcinoma using next generation deep sequencing. PLoS One 2013;8:e84486.

11 MacDonald BT, Tamai K, He X: Wnt/beta-catenin signaling: components, mechanisms, and diseases. Dev Cell 2009;17:9-26.

12 Zheng Z, Pan J, Chu B, Wong YC, Cheung AL, Tsao SW: Downregulation and abnormal expression of E-cadherin and beta-catenin in nasopharyngeal carcinoma: close association with advanced disease stage and lymph node metastasis. Hum Pathol 1999;30:458-466.

13 Wang FL, Guo X, Yuan TZ, Cao SM, Rao HL, Hou JH, Shao Q Li NW, Hong MH: Expression and clinical significance of Wnt-1 and beta-catenin in nasopharyngeal carcinoma. Chin J Cancer 2009;28:72-75.

14 Sun H, Liu M, Wu X, Yang C, Zhang Y, Xu Z, Gao K, Wang F: Overexpression of N-cadherin and $\beta$-catenin correlates with poor prognosis in patients with nasopharyngeal carcinoma. Oncol Lett 2017;13:17251730.

15 Hao D, Phan T, Jagdis A, Siever JE, Klimowicz AC, Laskin JJ, Thomson TA, Rose MS, Petrillo SK, Magliocco AM, Lau HY: Evaluation of E-cadherin, $\beta$-catenin and vimentin protein expression using quantitative immunohistochemistry in nasopharyngeal carcinoma patients. Clin Invest Med 2014;37:E320-330.

16 Li Z, Ren Y, Lin SX, Liang YJ, Liang HZ: Association of E-cadherin and beta-catenin with metastasis in nasopharyngeal carcinoma. Chin Med J (Engl) 2004;117:1232-1239.

17 Li G, Wang Y, Liu Y, Su Z, Liu C, Ren S, Deng T, Huang D, Tian Y, Qiu Y: miR-185-3p regulates nasopharyngeal carcinoma radioresistance by targeting WNT2B in vitro. Cancer Sci 2014;105:1560-1568. 


\section{Cellular Physiology Cell Physiol Biochem 2018;50:1929-1944 \begin{tabular}{l|l|l|l|l} 
DOI: 10.1159/000494873 & (O 2018 The Author(s). Published by S. Karger AG, Basel
\end{tabular} and Biochemistry Published online: 3 November 2018 www.karger.com/cpb}

He et al.: $\beta$-Catenin Overexpression Decreases CNE-2 Cell Radiosensitivity

18 Zhang G, Wang W, Yao C, Zhang S, Liang L, Han M, Ren J, Qi X, Zhang X, Wang S, Li L: Radiation-resistant cancer stem-like cell properties are regulated by PTEN through the activity of nuclear $\beta$-catenin in nasopharyngeal carcinoma. Oncotarget 2017;8:74661-74672.

19 Guigay J: Advances in nasopharyngeal carcinoma. Curr Opin Oncol 2008;20:264-269.

20 Yan H, Cao X, Wang J: Application of intensity-modulated radiation therapy in the treatment of nasopharyngeal carcinoma. Oncol Lett 2017;14:7773-7776.

-21 Lu H, Yao M: The current status of intensity-modulated radiation therapy in the treatment of nasopharyngeal carcinoma. Cancer Treat Rev 2008;34:27-36.

$\checkmark 22$ Cheng JC, Chao KS, Low D: Comparison of intensity modulated radiation therapy (IMRT) treatment techniques for nasopharyngeal carcinoma. Int J Cancer 2001;96:126-131.

$>23$ Lin S, Pan J, Han L, Zhang X, Liao X, Lu JJ: Nasopharyngeal carcinoma treated with reduced-volume intensity-modulated radiation therapy: report on the 3-year outcome of a prospective series. Int J Radiat Oncol Biol Phys 2009;75:1071-1078.

24 Chen X, Lei H, Liang Z, Li L, Qu S, Zhu X: Intensity-modulated radiotherapy controls nasopharyngeal carcinoma distant metastasis and improves survival of patients. Springerplus 2016;5:1459.

25 Chen J, Liu P, Wang Q, Wu L, Zhang X: Influence of intensity-modulated radiation therapy on the life quality of patients with nasopharyngeal carcinoma. Cell Biochem Biophys 2015;73:731-736.

-26 Guo Y, Zhu XD, Qu S, Li L, Su F, Li Y, Huang ST, Li DR: Identification of genes involved in radioresistance of nasopharyngeal carcinoma by integrating gene ontology and protein-protein interaction networks. Int J Oncol 2012;40:85-92.

-27 Rahmani F, Avan A, Hashemy SI, Hassanian SM: Role of Wnt/ $\beta$-catenin signaling regulatory microRNAs in the pathogenesis of colorectal cancer. J Cell Physiol 2018;233:811-817.

-28 Deitrick J, Pruitt WM: Wnt/ $\beta$ catenin-mediated signaling commonly altered in colorectal cancer. Prog Mol Biol Transl Sci 2016;144:49-68.

29 Monga SP: Role of Wnt/ $\beta$-catenin signaling in liver metabolism and cancer. Int J Biochem Cell Biol 2011;43:1021-1029.

-30 White BD, Chien AJ, Dawson DW: Dysregulation of Wnt/ $\beta$-catenin signaling in gastrointestinal cancers. Gastroenterology 2012;142:219-232.

-31 Krausova M, Korinek V: Wnt signaling in adult intestinal stem cells and cancer. Cell Signal 2014;26:570579.

-32 Santos JC, Carrasco-Garcia E, Garcia-Puga M, Aldaz P, Montes M, Fernandez-Reyes M, de Oliveira CC, Lawrie CH, Araúzo-Bravo MJ, Ribeiro ML, Matheu A: SOX9 elevation acts with canonical WNT signaling to drive gastric cancer progression. Cancer Res 2016;76:6735-6746.

-33 Chang HW, Roh JL, Jeong EJ, Lee SW, Kim SW, Choi SH, Park SK, Kim SY: Wnt signaling controls radiosensitivity via cyclooxygenase-2-mediated Ku expression in head and neck cancer. Int J Cancer 2008;122:100-107.

-34 Chang HW, Nam HY, Kim HJ, Moon SY, Kim MR, Lee M, Kim GC, Kim SW, Kim SY: Effect of $\beta$-catenin silencing in overcoming radioresistance of head and neck cancer cells by antagonizing the effects of AMPK on Ku70/ Ku80. Head Neck 2016;38:E1909-1917.

-35 Chang HW, Nam HY, Kim MR, Lee HJ, Seo JH, Lee SY, Kim SW, Kim SY: $\beta$-catenin silencing enhances radiation sensitivity through antagonizing effect of AMPK against Ku70/80 in head and neck cancer cells. Cancer Res 2014;74:4904.

-36 Zhang Q, Gao M, Luo G, Han X, Bao W, Cheng Y, Tian W, Yan M, Yang G, An J: Enhancement of radiation sensitivity in lung cancer cells by a novel small molecule inhibitor that targets the $\beta$-catenin/Tcf4 interaction. PLoS One 2016;11:e0152407.

37 Allen C, Her S, Jaffray DA: Radiotherapy for cancer: present and future. Adv Drug Deliv Rev 2017;109:1-2.

-38 Lomax ME, Folkes LK, O’Neill P: Biological consequences of radiation-induced DNA damage: relevance to radiotherapy. Clin Oncol (R Coll Radiol) 2013;25:578-585.

39 Willers H, Dahm-Daphi J, Powell SN: Repair of radiation damage to DNA. Br J Cancer 2004;90:1297-1301.

40 Harris AL: DNA repair: relationship to drug and radiation resistance, metastasis and growth factors. Int J Radiat Biol Relat Stud Phys Chem Med 1985;48:675-690.

41 Chandra A, Lin T, Zhu J, Tong W, Huo Y, Jia H, Zhang Y, Liu XS, Cengel K, Xia B, Qin L: PTH1-34 blocks radiation-induced osteoblast apoptosis by enhancing DNA repair through canonical Wnt pathway. J Biol Chem 2015;290:157-167. 


\section{Cellular Physiology Cell Physiol Biochem 2018;50:1929-1944 and Biochemistry \begin{tabular}{c|c|c|} 
DOI: 10.1159/000494873 \\
Published 2018 The Author(s). Published by S. Karger AG, Basel
\end{tabular}

He et al.: $\beta$-Catenin Overexpression Decreases CNE-2 Cell Radiosensitivity

42 Deng R, Tang J, Ma JG, Chen SP, Xia LP, Zhou WJ, Li DD, Feng GK, Zeng YX, Zhu XF: PKB/Akt promotes DSB repair in cancer cells through upregulating Mre11 expression following ionizing radiation. Oncogene 2011;30:944-955.

43 Wilson GD: Radiation and the cell cycle, revisited. Cancer Metastasis Rev 2004;23:209-225.

$\checkmark 44$ Zhou BB, Elledge SJ: The DNA damage response: putting checkpoints in perspective. Nature 2000;408:433439.

45 Le AP, Zhang LL, Liu W, Shi YF: Cantharidin inhibits cell proliferation and induces apoptosis through G2/M phase cell cycle arrest in hepatocellular carcinoma stem cells. Oncol Rep 2016;35:2970-2976.

-46 Liang Y, Li X, He X, Qiu X, Jin XL, Zhao XY, Xu RZ: Polyphyllin I induces cell cycle arrest and apoptosis in human myeloma cells via modulating $\beta$-catenin signaling pathway. Eur J Haematol 2016;97:371-378.

-47 Li Z, Wang C, Prendergast GC, Pestell RG: Cyclin D1 functions in cell migration. Cell Cycle 2006;5:24402442.

48 Su H, Jin X, Shen L, Fang Y, Fei Z, Zhang X, Xie C, Chen X: Inhibition of cyclin D1 enhances sensitivity to radiotherapy and reverses epithelial to mesenchymal transition for esophageal cancer cells. Tumour Biol 2016;37:5355-5363.

-49 Jirawatnotai S, Hu Y, Michowski W, Elias JE, Becks L, Bienvenu F, Zagozdzon A, Goswami T, Wang YE, Clark AB, Kunkel TA, van Harn T, Xia B, Correll M, Quackenbush J, Livingston DM, Gygi SP, Sicinski P: A function for cyclin D1 in DNA repair uncovered by protein interactome analyses in human cancers. Nature 2011;474:230-234.

50 Rudner J, Belka C, Marini P, Wagner RJ, Faltin H, Lepple-Wienhues A, Bamberg M, Budach W: Radiation sensitivity and apoptosis in human lymphoma cells. Int J Radiat Biol 2001;77:1-11.

51 Steel GG: The case against apoptosis. Acta Oncol 2001;40:968-975.

-52 Kroemer G, Petit P, Zamzami N, Vayssière JL, Mignotte B: The biochemistry of programmed cell death. FASEB J 1995;9:1277-1287.

53 Haas-Kogan DA, Kogan SC, Levi D, Dazin P, T’AngA, Fung YK, Israel MA: Inhibition of apoptosis by the retinoblastoma gene product. EMBO J 1995;14:461-472.

54 Chen SQ, Guttridge DC, You ZB, Zhang ZC, Fribley A, Mayo MW, Kitajewski J, Wang CY: WNT-1 signaling inhibits apoptosis by activating $\beta$-catenin/T cell factor-mediated transcription. J Cell Biol 2001;152:87-96.

55 Li K, Zhou ZY, Ji PP, Luo HS: Knockdown of $\beta$-catenin by siRNA influences proliferation, apoptosis and invasion of the colon cancer cell line SW480. Oncol Lett 2016;11:3896-3900.

56 Leal LF, Bueno AC, Gomes DC, Abduch R, Castro M, Antonini SR: Inhibition of the Tcf/beta-catenin complex increases apoptosis and impairs adrenocortical tumor cell proliferation and adrenal steroidogenesis. Oncotarget 2015;6:43016-43032.

57 Dickey A, Schleicher S, Leahy K, Hu R, Hallahan D, Thotala DK: GSK-3 $\beta$ inhibition promotes cell death, apoptosis, and in vivo tumor growth delay in neuroblastoma Neuro-2A cell line. J Neurooncol 2011;104:145-153.

58 Zhan T, Rindtorff N, Boutros M: Wnt signaling in cancer. Oncogene 2017;36:1461-1473.

-59 Dong Z, Zhou L, Han N, Zhang M, Lyu X: Wnt/ $\beta$-catenin pathway involvement in ionizing radiation-induced invasion of U87 glioblastoma cells. Strahlenther Onkol 2015;191:672-680. 